\title{
Desulfovibrio gabonensis sp. nov., a New Moderately Halophilic Sulfate-Reducing Bacterium Isolated from an Oil Pipeline
}

\author{
C. TARDY-JACQUENOD, ${ }^{1}$ M. MAGOT, ${ }^{2}$ F. LAIGRET, ${ }^{3}$ M. KAGHAD, ${ }^{2}$ B. K. C. PATEL, ${ }^{4}$ \\ J. GUEZENNEC ${ }^{5}$ R. MATHERON, ${ }^{6}$ AND P. CAUMETTE ${ }^{1 *}$ \\ Laboratoire d'Océanographie Biologique, Université de Bordeaux I, 33120 Arcachon, ${ }^{1}$ Sanofi Recherche, Centre de Labège, \\ F-31676 Labège, ${ }^{2}$ Laboratoire de Biologie Cellulaire et Moléculaire, Institut National de Recherche Agronomique and \\ Université de Bordeaux II, 33883 Villenave d'Ornon Cedex, ${ }^{3}$ IFREMER, Centre de Brest, 29280 Plouzané, ${ }^{5}$ \\ and Laboratoire de Microbiologie, Université des Sciences et Techniques de Saint Jérôme, \\ F-13397 Marseille cedex 20, ${ }^{6}$ France, and Faculty of Science and Technology, \\ Griffith University, Nathan, Brisbane, Australia $4111^{4}$
}

\begin{abstract}
Two moderately halophilic sulfate-reducing bacteria were isolated from an African oil pipeline and designated strains SEBR 3640 and SEBR $2840^{\mathrm{T}}$ ( $\mathrm{T}=$ type strain). Both of these strains possessed traits that define the genus Desulfovibrio. The cells of both isolates were motile curved rods that had a single polar flagellum and contained desulfoviridin, and both isolates utilized lactate, pyruvate, malate, fumarate, succinate, and ethanol in the presence of sulfate. Sulfite, thiosulfate, and elemental sulfur were also used as electron acceptors in the presence of lactate. However, both strains tolerated higher concentrations of $\mathrm{NaCl}$ (up to $17 \%$ ) than all other Desulfovibrio species except Desulfovibrio halophilus, which tolerated a similar level of NaCl. The results of a $16 \mathrm{~S}$ rRNA gene sequence analysis also placed the designated type strain, strain SEBR 2840, in the genus Desulfovibrio but revealed that this organism was significantly different from $D$. halophilus and all other validly described Desulfovibrio species. On the basis of our results, we propose that strain SEBR $2840^{\mathrm{T}}$ is a member of a new species of the genus Desulfovibrio, Desulfovibrio gabonensis. The type strain of $D$. gabonensis is strain SEBR 2840 (= DSM 10636).
\end{abstract}

The presence of sulfate-reducing bacteria (SRB) in oil field waters has been recognized for a long time, and the activities of these microorganisms are closely linked to the history of oil. In 1926, Bastin et al. (3) studied the SRB communities in oil fields. After this pioneering work, several microbiological studies showed that SRB communities were widely distributed in most of the oil fields investigated $(1,5,19)$.

In the course of a survey of different oil fields, we isolated several strains of SRB. Two strains, designated strains SEBR $2840^{\mathrm{T}}$ ( $\mathrm{T}=$ type strain) and SEBR 3640 , were characterized further; these strains were isolated from water samples obtained from two oil pipelines transporting the oil produced at an offshore oil field to onshore facilities on the coast of Gabon (West Africa). Both strains were moderately halophilic, curved, rod-shaped organisms and on the basis of their morphological and physiological traits were assigned to the genus Desulfovibrio. The results of a 16S rRNA gene sequence analysis of strain SEBR $2840^{\mathrm{T}}$ indicated that it was not related to any previously described Desulfovibrio species, and we propose that this strain should be assigned to a new species, Desulfovibrio gabonensis. Strain SEBR 2840 is the type strain of this species.

\section{MATERIALS AND METHODS}

Sources of the isolates. Strain SEBR $2840^{\mathbf{T}}$ was isolated in February 1990 from a water sample taken from an oil pipeline linking offshore production platforms to onshore treatment facilities.

Strain SEBR 3640 was isolated 1 year later from another pipeline in the same offshore oil field.

Sampling and primary cultures of SRB were grown as described previously (4, 18). The total salinity of the culture media and the incubation temperature were

\footnotetext{
* Corresponding author. Mailing address: Laboratoire d'Océanographie Biologique, Université de Bordeaux I, 2 rue du Pr. Jolyet, 33120 Arcachon, France. Phone: (33).56.22.39.01. Fax: (33).56.83.51 .04 .
}

adjusted so that they corresponded to the in situ conditions $\left(80 \mathrm{~g} / \mathrm{liter}\right.$ and $30^{\circ} \mathrm{C}$, respectively).

Desulfovibrio halophilus and Desulfohalobium retbaense were provided by $\mathbf{P}$ Caumette and B. Ollivier, respectively.

Media and culture conditions. SRB were isolated by the streak plate method, as described elsewhere (18). The culture medium used for isolation contained (per liter of distilled water) $2.0 \mathrm{~g}$ of $\mathrm{Na}_{2} \mathrm{SO}_{4}, 0.3 \mathrm{~g}$ of $\mathrm{KHCO}_{3}, 1.0 \mathrm{~g} \mathrm{of} \mathrm{CaCl}_{2}$. $2 \mathrm{H}_{2} \mathrm{O}, 60 \mathrm{~g}$ of $\mathrm{NaCl}, 6.0 \mathrm{~g}$ of $\mathrm{MgSO}_{4} \cdot 7 \mathrm{H}_{2} \mathrm{O}, 1 \mathrm{ml}$ of a $0.4 \% \mathrm{FeSO}_{4} \cdot 7 \mathrm{H}_{2} \mathrm{O}$ solution, $3.0 \mathrm{~g}$ of MOPS (morpholinopropane-sulfonic acid) buffer, $1.0 \mathrm{~g}$ of $\mathrm{NH}_{4} \mathrm{Cl}, 6 \mathrm{ml}$ of a $60 \%$ sodium lactate solution, $1.0 \mathrm{~g}$ of sodium acetate, $1.0 \mathrm{~g}$ of yeast extract, $0.5 \mathrm{~g}$ of cysteine hydrochloride, and $16 \mathrm{~g}$ of agar. The $\mathrm{pH}$ was adjusted to 7.4 , and the medium was anaerobically distributed into bottles and autoclaved for $30 \mathrm{~min}$ at $105^{\circ} \mathrm{C}$.

The final medium used for growth and maintenance of the strains was pre-

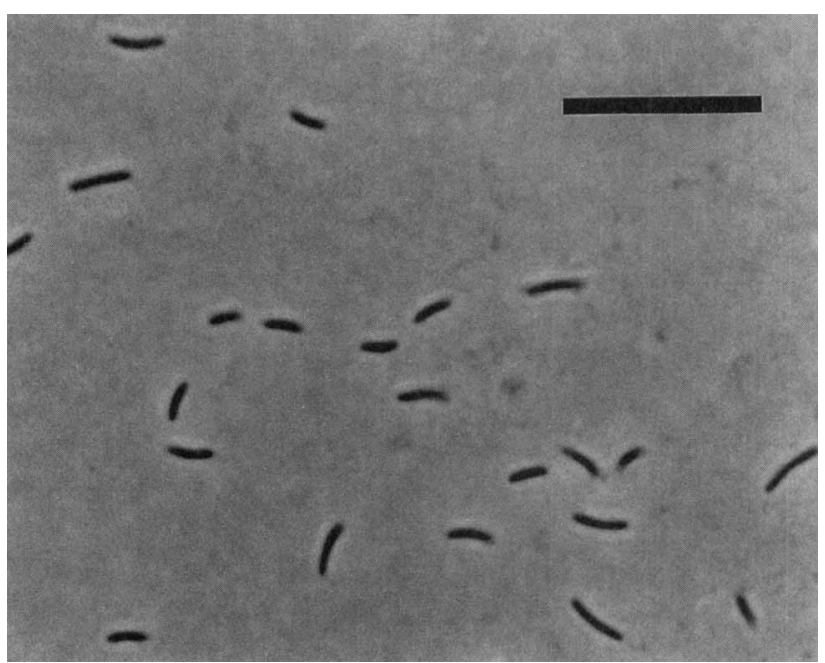

FIG. 1. Phase-contrast photomicrograph of Desulfovibrio gabonensis SEBR $2840^{\mathrm{T}}$ grown with lactate as a carbon and energy source. Bar $=10 \mu \mathrm{m}$. 


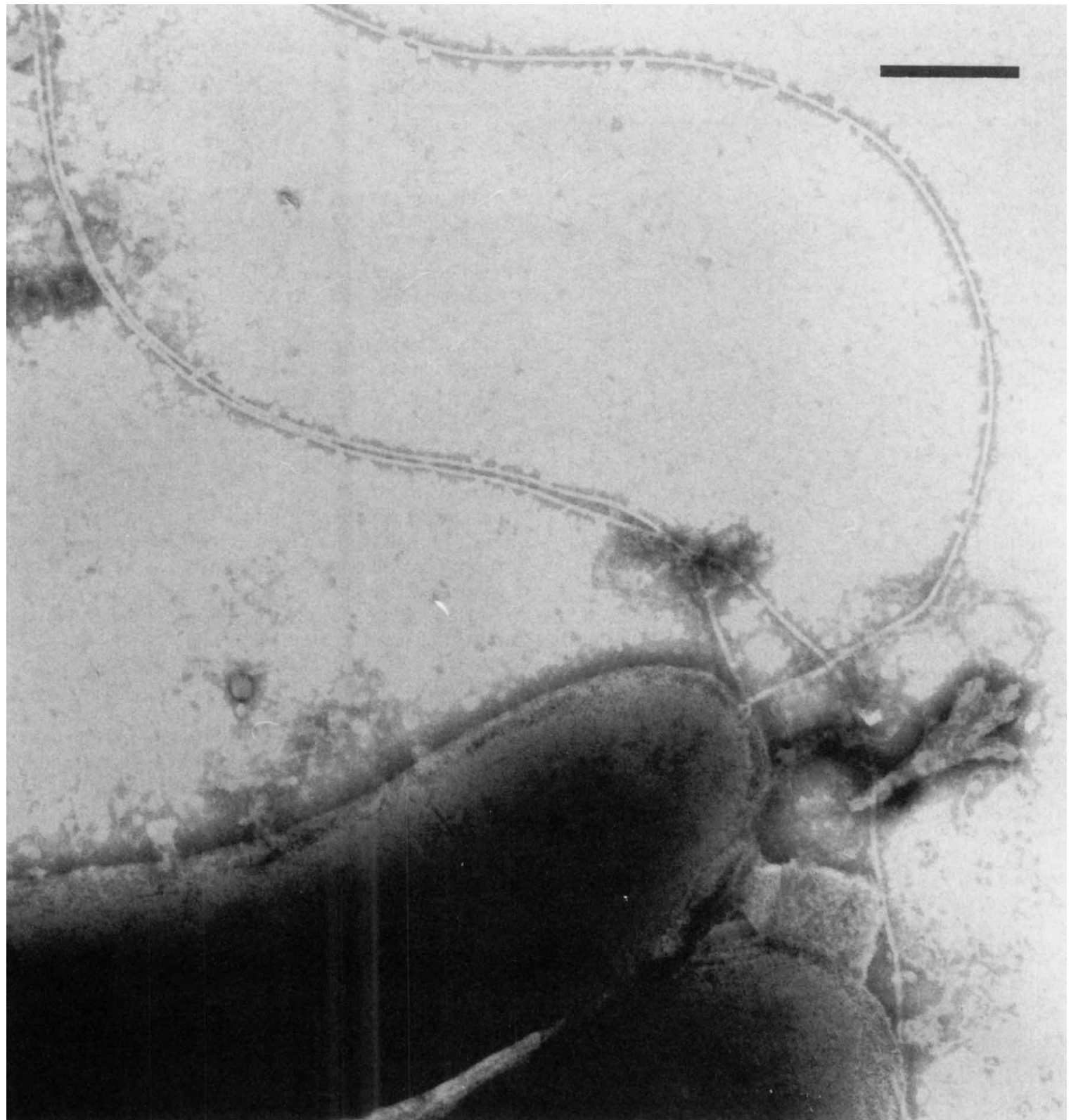

FIG. 2. Transmission electron micrograph of Desulfovibrio gabonensis SEBR $2840^{\mathrm{T}}$ after negative staining. Bar $=0.3 \mu \mathrm{m}$.

pared as described by Pfennig et al. (24). It was supplemented with $50 \mathrm{~g}$ of $\mathrm{NaCl}$ per liter, $3.3 \mathrm{~g}$ of $\mathrm{MgCl}_{2} \cdot 6 \mathrm{H}_{2} \mathrm{O}$ per liter, and $1.6 \mathrm{~g}$ of $\mathrm{MgSO}_{4} \cdot 7 \mathrm{H}_{2} \mathrm{O}$ per liter.

The purity of strains was checked both by phase-contrast microscopy and by performing growth tests (both aerobically and anaerobically) in sulfate-free TYG medium (8).

Desulfovibrio halophilus and Desulfohalobium retbaense were grown as previously described $(9,21)$.

Morphology. An Olympus model BH-2 phase-contrast microscope was used for microscopy. Photomicrographs were obtained by using the agar slide methods (23). Cells were negatively stained by using $1 \%$ phosphotungstic acid, and electron photomicrographs were obtained with a JEOL model $1200 \mathrm{EX}$ transmission electron microscope.

Metabolism and physiology. The physiological and metabolic tests used to characterize the strains included tests to determine utilization of different carbon substrates and energy sources, utilization of a variety of electron acceptors, fermentative growth, temperature, $\mathrm{pH}$, and salinity optima, and vitamin requirements; the tests used have been described previously (18).

Pigments. The presence of desulfoviridin in cell extracts was determined by the method of Widdel and Pfennig (32). Briefly, cell extracts were prepared by ultrasonically disrupting bacterial cells for $15 \mathrm{~min}$ at $10 \mathrm{~W}$ with a Vibra Cell
72446 apparatus (Bioblock Scientific, Strasbourg, France) and then centrifuging the preparations at $25,000 \times g$ for $15 \mathrm{~min}$ and at $140,000 \times g$ for $90 \mathrm{~min}$. The resulting cell extract was scanned with a UV spectrophotometer (Safas, Monaco, France).

Lipid analysis. Lipid extraction, esterification, fatty acid purification, and quantification by gas chromatography were performed as previously described (30). Briefly, lipids from lyophilized cells ( 50 to $100 \mathrm{mg}$ ) were extracted by using a modified Bligh-Dyer method $(6,29)$. The extracted lipids were fractionated into neutral lipids, glycolipids, and polar lipids by silicic acid column chromatography by using appropriate volumes of chloroform, acetone, and methanol, respectively. The phospholipids were subjected to mild alkaline methanolysis, and the resulting fatty acid methyl esters were purified by thin-layer chromatography and analyzed by gas chromatography and gas chromatography-mass spectrometry (15). The position and geometry of the double bond of each monosaturated fatty acid were determined by using the dimethyl disulfide derivatives and the procedure described previously $(15,20)$.

Fatty acid nomenclature. In this paper a shorthand nomenclature is used, which is in the form of numbers separated by a colon. The number before the colon indicates the carbon chain length, and the number after the colon corresponds to the number of double bonds. The position of the double bond is 
TABLE 1. Electron donors and acceptors utilized by Desulfovibrio gabonensis SEBR $2840^{\mathrm{T}}$ and SEBR 3640

\begin{tabular}{lcc}
\hline \multicolumn{1}{c}{$\begin{array}{c}\text { Electron donor } \\
\text { or acceptor }\end{array}$} & \multicolumn{2}{c}{ Utilization by: } \\
\cline { 2 - 3 } & SEBR $2840^{\mathrm{T}}$ & SEBR 3640 \\
\hline Electron donors & & \\
$\mathrm{H}_{2}+\mathrm{CO}_{2}\left(10^{5} \mathrm{~Pa}\right)$ & ${ }^{b}$ & - \\
$\mathrm{H}_{2}\left(10^{5} \mathrm{~Pa}\right)+$ acetate $(10 \mathrm{mM})$ & + & + \\
Lactate $(10 \mathrm{mM})$ & + & + \\
Pyruvate $(10 \mathrm{mM})$ & + & + \\
Malate $(10 \mathrm{mM})$ & + & + \\
Fumarate $(10 \mathrm{mM})$ & + & + \\
Succinate $(10 \mathrm{mM})$ & + & + \\
Formate $(10 \mathrm{mM})$ & + & + \\
Acetate $(10 \mathrm{mM})$ & - & - \\
Ethanol $(10 \mathrm{mM})$ & + & + \\
Butanol $(10 \mathrm{mM})$ & ++ & + \\
& & + \\
Electron acceptors & + & + \\
Sulfate $(20 \mathrm{mM})$ & + & + \\
Sulfite $(10 \mathrm{mM})$ & + & - \\
Thiosulfate $(10 \mathrm{mM})$ & + & + \\
Sulfur $(10 \mathrm{mM})$ & + & + \\
Nitrate $(10$ & + & + \\
\hline
\end{tabular}

${ }^{a}$ Electron donors were tested in the presence of $30 \mathrm{mM}$ sulfate. The following substrates were tested in the presence of sulfate but were not utilized: $10 \mathrm{mM}$ glycerol, $10 \mathrm{mM}$ butyrate, $5 \mathrm{mM}$ isobutyrate, $5 \mathrm{mM}$ valerate, $2 \mathrm{mM}$ crotonate, 2 $\mathrm{mM}$ octanoate, $2 \mathrm{mM}$ nonanoate, $5 \mathrm{mM}$ palmitate, $2 \mathrm{mM}$ tartrate, $5 \mathrm{mM}$ benzoate, $5 \mathrm{mM}$ citrate, $5 \mathrm{mM}$-ketoglutarate, $10 \mathrm{mM}$ gluconate, $5 \mathrm{mM}$ glutarate, $5 \mathrm{mM}$ gallate, $2 \mathrm{mM}$ glycolate, $2 \mathrm{mM}$ thioglycolate, $2 \mathrm{mM}$ thioacetamide, $10 \mathrm{mM}$ methanol, $10 \mathrm{mM}$ isopropanol, $5 \mathrm{mM}$ acetone, $5 \mathrm{mM}$ glucose, $5 \mathrm{mM}$ fructose, 0.5 $\mathrm{mM}$ catechol, $5 \mathrm{mM}$ alanine, $10 \mathrm{mM}$ lysine, $10 \mathrm{mM}$ methionine, $5 \mathrm{mM}$ cysteine, $5 \mathrm{mM}$ glutamate, $5 \mathrm{mM}$ aspartate, $5 \mathrm{mM}$ betaine, $5 \mathrm{mM}$ glycine, $0.25 \mathrm{M}$ indole, $0.5 \mathrm{mM}$ phenol, $2 \mathrm{mM}$ nicotinate, $0.5 \mathrm{~g}$ of peptone per liter, $0.5 \mathrm{~g}$ of Casamino Acids per liter, and $0.5 \mathrm{~g}$ of yeast extract per liter.

${ }^{b}-$, no growth; + , good growth; $(+)$, slight growth.

${ }^{c}$ Electron acceptors were tested in the presence of $10 \mathrm{mM}$ lactate as a carbon and energy source.

indicated by the symbol $\omega$, followed by the number of carbons from the methyl end. The geometry of the double bonds is indicated by cis or trans.

$\mathrm{G}+\mathrm{C}$ content of the DNA. The $\mathrm{G}+\mathrm{C}$ content of strain SEBR $2840^{\mathrm{T}}$ DNA was determined by high-performance liquid chromatography at the Identification Service of the Deutsche Sammlung von Mikroorganismen und Zellkulturen, Braunschweig, Germany.

16S rRNA sequencing. The $16 \mathrm{~S}$ rRNA gene of SEBR $2840^{\mathrm{T}}$ was amplified by adding $1 \mu \mathrm{l}$ of cell culture to a thermocycler microtube containing $5 \mu \mathrm{l}$ of $10 \times$ Taq buffer (Pharmacia, Uppsala, Sweden), $100 \mathrm{ng}$ of each primer, and $3 \mu \mathrm{l}$ of 25 $\mathrm{mM} \mathrm{MgCl} 2 \cdot 6 \mathrm{H}_{2} \mathrm{O}$. The volume was adjusted to $47.5 \mu \mathrm{l}$ with sterile distilled water.

The two primers which we used (5'-AGAGTTTGATCCTGGCTCAG-3' and $5^{\prime}$-AAGGAGGTGATCCAGCC-3') were described by Weisburg et al. (28). The samples were denatured by heating them for $30 \mathrm{~min}$ at $92^{\circ} \mathrm{C}$, and a mixture containing $2 \mu \mathrm{l}$ of deoxynucleoside triphosphates (each at a concentration of 5 $\mathrm{mM}$ ) and $0.5 \mu \mathrm{l}$ of Taq polymerase (Pharmacia) was added. The samples were then placed in a Hybrid thermal reactor thermocycler and subjected to 35 cycles, each of which consisted of $1 \mathrm{~min}$ at $93^{\circ} \mathrm{C}, 1 \mathrm{~min}$ at $53^{\circ} \mathrm{C}$, and $2.5 \mathrm{~min}$ at $72^{\circ} \mathrm{C}$; this was followed by a final elongation step consisting of $10 \mathrm{~min}$ at $72^{\circ} \mathrm{C}$.

The PCR products were purified by using the spun-column chromatography procedure and a Sephacryl S400 gel (Pharmacia). The purified products were sequenced directly with an Applied Biosystems model 373 automated DNA sequencer by using a prism dideoxy terminator cycle sequencing kit (Applied Biosystems, Ltd., Foster City, Calif.). The primers used were the primers used for PCR amplification and internal primers derived from partial sequence data.

The 16S rRNA genes of Desulfohalobium retbaense and Desulfovibrio halophilus were amplified, purified, and sequenced as previously described $(10,17,26)$.

A search for sequences similar to the $16 \mathrm{~S}$ rRNA sequence of SEBR $2840^{\mathrm{T}}$ was performed by using the SIMILARITY-RANK tool of the Ribosomal Databank Project (22), the blast (2) and fasta (33) software, and the GenBank and EMBL databases. Sequences were aligned manually with an alignment editor, ae2. Positions of sequence and alignment uncertainty were omitted from the analysis, and pairwise evolutionary distances were determined by using the correction factor of Jukes and Cantor (16). Dendrograms were constructed from evolutionary distances by using the neighbor-joining package that forms part of the
PHYLIP package of software programs (14). The tree topology was reexamined by using 100 bootstrapped data sets.

Nucleotide sequence accession numbers. The sequences of the 16S rRNA genes of strain SEBR $2840^{\mathrm{T}}$, Desulfohalobium retbaense, and Desulfovibrio halophilus have been deposited in the GenBank and EMBL databases under accession numbers U31080, U48244, and U48243, respectively.

\section{RESULTS}

Cell morphology. The cells of strains SEBR $2840^{\mathrm{T}}$ and SEBR 3640 were actively motile vibrioid cells that occurred singly or in pairs (Fig. 1). Each cell moved by means of a polar flagellum (Fig. 2). Sporulation was never observed. The cells were $0.4 \mu \mathrm{m}$ wide and 2 to $4 \mu \mathrm{m}$ long. Gram staining was negative.

Physiological properties. The substrates tested as possible energy and carbon sources in the presence of sulfate as an electron acceptor are listed in Table 1. Strains SEBR $2840^{\mathrm{T}}$ and SEBR 3640 grew well on lactate, pyruvate, malate, fumarate, succinate, and ethanol. Lactate was incompletely oxidized to acetate and $\mathrm{CO}_{2}$. Slight growth occurred in the presence of butanol, and small amounts of sulfide were produced. $\mathrm{H}_{2}$ and formate were used as electron donors in the presence of acetate. $\mathrm{CO}_{2}$ could not be used as a sole source of carbon by either strain. The ability to use different electron acceptors was tested in minimal medium supplemented with lactate. Both strains reduced sulfate, sulfite, thiosulfate, and sulfur to sulfide. Nitrate could not be used.

In sulfate-free medium, strains SEBR $2840^{\mathrm{T}}$ and SEBR 3640 grew well with malate, fumarate, and pyruvate as sole carbon and energy sources. Glucose, fructose, succinate, lactate, cysteine, and glycerol were never fermented.

In synthetic medium that was supplemented with lactate and sulfate and contained only $0.01 \%$ yeast extract, both strains grew in the presence of 1 to $17 \% \mathrm{NaCl}$. Optimum growth of strain SEBR $2840^{\mathrm{T}}$ occurred in the presence of 5 to $6 \% \mathrm{NaCl}$, and optimum growth of strain SEBR 3640 occurred in the presence of 6 to $8 \% \mathrm{NaCl}$. The optimum $\mathrm{pH}$ was 6.9 to 7.3 , and strain SEBR $2840^{\mathrm{T}}$ grew well at $\mathrm{pH}$ values between 6.4 and 8.2 . The optimum temperatures were $30^{\circ} \mathrm{C}$ for strain SEBR $2840^{\mathrm{T}}$ and $38^{\circ} \mathrm{C}$ for strain SEBR 3640 . These strains were mesophilic organisms; no growth occurred at $50^{\circ} \mathrm{C}$ or above, and both strains grew well at $20^{\circ} \mathrm{C}$. Both strains did not grow without

TABLE 2. Fatty acid profiles of Desulfovibrio gabonensis SEBR $2840^{\mathrm{T}}$ and SEBR 3640

\begin{tabular}{lcr}
\hline & \multicolumn{2}{c}{$\%$ in: } \\
\cline { 2 - 3 } Fatty acid & SEBR $2840^{\mathrm{T}}$ & SEBR 3640 \\
\hline iso $\mathrm{C}_{14: 0}$ & 5.21 & 5.62 \\
$\mathrm{C}_{14: 0}$ & 14.63 & 12.85 \\
iso $\mathrm{C}_{15: 1 \omega 7}$ & 0.30 & 0.33 \\
iso $\mathrm{C}_{15: 0}$ & 7.90 & 9.22 \\
anteiso $\mathrm{C}_{15: 0}$ & 38.44 & 42.45 \\
$\mathrm{C}_{15: 0}$ & 1.01 & 1.36 \\
iso $\mathrm{C}_{16: 0}$ & 0.78 & 0.87 \\
$\mathrm{C}_{16: 1 \omega 9}$ & & 0.77 \\
$\mathrm{C}_{16: 1 \omega 7 \mathrm{c}}$ & 0.84 & 0.22 \\
$\mathrm{C}_{16: 0}$ & 8.85 & 6.74 \\
iso $\mathrm{C}_{17: 0}$ & 0.08 & 0.08 \\
anteiso & 0.20 & 0.25 \\
$\mathrm{C}_{17: 0}$ & 0.52 & 0.71 \\
iso $\mathrm{C}_{18: 0}$ & 0.26 & 0.25 \\
$\mathrm{C}_{18: 1 \omega 7 \mathrm{c}}$ & 5.91 & 4.89 \\
$\mathrm{C}_{18: 1 \omega 7 \mathrm{t}}$ & & 0.25 \\
$\mathrm{C}_{18: 1 \omega 5 \mathrm{c}}$ & & 0.38 \\
$\mathrm{C}_{18: 0}$ & 15.06 & 12.77 \\
\hline
\end{tabular}


TABLE 3. Evolutionary similarity matrix

\begin{tabular}{|c|c|c|c|c|c|c|c|c|c|c|c|c|c|c|c|c|c|c|c|c|c|c|}
\hline \multirow[b]{2}{*}{ Species } & \multicolumn{22}{|c|}{$\%$ Sequence similarity } \\
\hline & 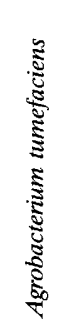 & 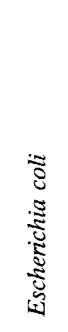 & 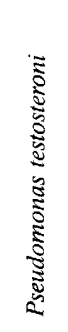 & 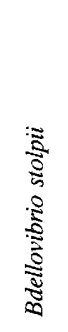 & 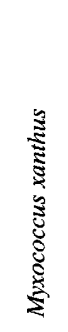 & 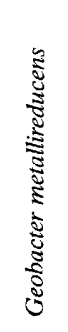 & 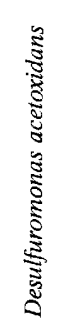 & 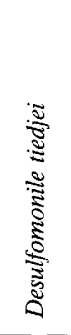 & 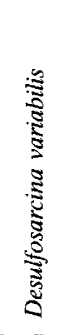 & 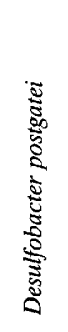 & 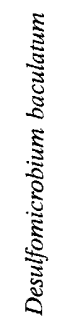 & 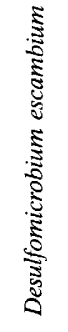 & 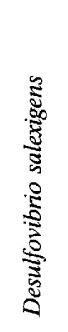 & 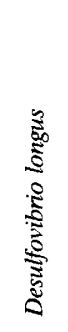 & 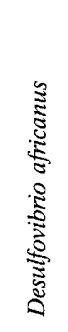 & 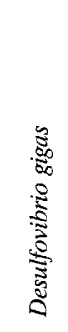 & 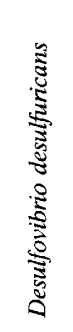 & 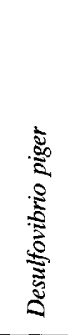 & 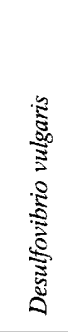 & 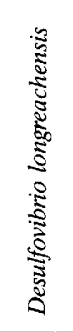 & 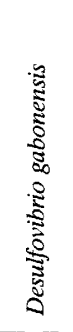 & 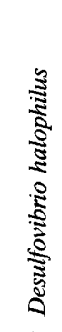 \\
\hline Escherichia coli & 80.8 & & & & & & & & & & & & & & & & & & & & & \\
\hline Pseudomonas testosteroni & 78.4 & 81.2 & & & & & & & & & & & & & & & & & & & & \\
\hline Bdellovibrio stolpii & 80.4 & 79.0 & 77.3 & & & & & & & & & & & & & & & & & & & \\
\hline Myxococcus xanthus & 81.1 & 79.5 & 77.5 & 81.4 & & & & & & & & & & & & & & & & & & \\
\hline Geobacter metallireducens & 81.4 & 83.5 & 80.0 & 83.0 & 84.8 & & & & & & & & & & & & & & & & & \\
\hline Desulfuromonas acetoxidans & 82.3 & 81.6 & 79.2 & 83.9 & 84.5 & 90.6 & & & & & & & & & & & & & & & & \\
\hline Desulfomonile tiedjei & 81.4 & 81.4 & 79.5 & 83.1 & 84.2 & 87.6 & $\begin{array}{l}87.1 \\
86.6\end{array}$ & 86.9 & & & & & & & & & & & & & & \\
\hline Desulfosarcina variabilis & 81.7 & 81.4 & 78.0 & 82.9 & 82.9 & $\begin{array}{l}86.3 \\
84.9\end{array}$ & $\begin{array}{l}86.6 \\
85.3\end{array}$ & 83.6 & 87.8 & & & & & & & & & & & & & \\
\hline $\begin{array}{l}\text { Desulfobacter postgatei } \\
\text { Desulfomicrobium baculatum }\end{array}$ & $\begin{array}{l}79.0 \\
82.1\end{array}$ & $\begin{array}{l}79.5 \\
80.5\end{array}$ & $\begin{array}{l}77.7 \\
77.7\end{array}$ & $\begin{array}{l}82.6 \\
82.5\end{array}$ & $\begin{array}{l}81.0 \\
80.9\end{array}$ & $\begin{array}{l}84.9 \\
85.5\end{array}$ & $\begin{array}{l}85.3 \\
83.9\end{array}$ & 82.3 & 84.9 & 83.9 & & & & & & & & & & & & \\
\hline Desulfomicrobium escambium & 82.6 & 81.4 & 78.3 & 82.9 & 81.5 & 86.4 & 84.4 & 82.9 & 85.0 & 84.4 & 97.9 & & & & & & & & & & & \\
\hline Desulfovibrio salexigens & 81.5 & 80.2 & 77.5 & 81.6 & 80.9 & 83.1 & 83.9 & 81.5 & 82.6 & 82.2 & 87.3 & 87.2 & & & & & & & & & & \\
\hline Desulfovibrio longus & 80.8 & 80.3 & 77.1 & 82.2 & 80.7 & 83.4 & 84.1 & 83.2 & 84.1 & 83.1 & 87.7 & 87.5 & 90.0 & & & & & & & & & \\
\hline Desulfovibrio africanus & 79.8 & 81.1 & 78.7 & 81.1 & 82.1 & 84.3 & 84.3 & 81.4 & 83.9 & 83.1 & 88.2 & 88.5 & 88.4 & 88.6 & & & & & & & & \\
\hline Desulfovibrio gigas & 79.7 & 80.4 & 78.1 & 81.6 & 80.9 & 83.9 & 85.0 & 80.8 & 83.7 & 83.4 & 87.2 & 87.2 & 87.2 & 88.0 & 87.9 & & & & & & & \\
\hline Desulfovibrio desulfuricans & 80.7 & 80.7 & 77.1 & 81.7 & 80.7 & 84.4 & 84.3 & 81.8 & 82.8 & 83.6 & 88.7 & 89.0 & 87.9 & 89.9 & 88.7 & 89.3 & & & & & & \\
\hline Desulfovibrio piger & 79.8 & 80.1 & 77.8 & 81.7 & 80.3 & 83.5 & 84.3 & 80.8 & 82.9 & 83.5 & 87.2 & 88.0 & 86.8 & 88.5 & 87.1 & 89.2 & 94.7 & & & & & \\
\hline Desulfovibrio vulgaris & 80.1 & 80.2 & 77.6 & 79.8 & 78.8 & 84.3 & 83.5 & 80.3 & 83.5 & 81.2 & 87.0 & 87.3 & 89.0 & 88.9 & 89.4 & 87.3 & 91.2 & 9 & & & & \\
\hline Desulfovibrio longreachensis & 80.9 & 80.3 & 77.4 & 81.0 & 80.3 & 84.3 & 83.9 & 80.5 & 83.5 & 82.3 & 87.5 & 88.2 & 88.2 & 88.9 & 88.3 & 89.6 & 92.1 & 92.1 & 4.5 & & & \\
\hline Desulfovibrio gabonensis & 79.2 & 79.6 & 77.6 & 81.1 & 81.1 & 83.6 & 83.1 & 80.9 & 83.4 & 81.8 & 86.6 & 87.6 & 90.0 & 89.0 & 89.2 & 91.1 & 88.6 & 88.2 & 89.3 & & & \\
\hline Desulfovibrio halophilus & 79.5 & 79.8 & 76.8 & 80.5 & 79.4 & 81.7 & 82.2 & 81.5 & 82.8 & 80.7 & 86.2 & 86.2 & 88.5 & 88.7 & 86.9 & 85.1 & 86.4 & 85.0 & & 6.5 & 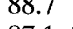 & \\
\hline Desulfohalobium retbaense & 81.1 & 80.5 & 77.8 & 79.5 & 80.1 & 83.9 & 83.1 & 81.4 & 82.4 & 81.7 & 86.6 & 87.2 & 86.3 & 84.6 & 84.6 & 86.9 & 85.5 & 85.2 & 84.6 & 85.1 & 87.1 & 84.1 \\
\hline
\end{tabular}

vitamins (V7 solution [24]) or yeast extract in the culture medium after five transfers. Under optimum growth conditions, the doubling time of each culture was $10 \mathrm{~h}$.

Pigment. Spectra of the soluble fraction exhibited the characteristic absorption band of desulfoviridin at $631 \mathrm{~nm}$.

Lipid characteristics. The fatty acid profiles are shown in Table 2. Branched-chain saturated fatty acids accounted for 53 to $58 \%$ of the total fatty acids, with anteiso $\mathrm{C}_{15 ; 0}$ predominating (this fatty acid accounted for up to $40 \%$ of the total fatty acids). With the exception of $\mathrm{C}_{18: 1 \omega 7 \mathrm{c}}$ (which accounted for $5 \%$ of the total fatty acids), only traces of monounsaturated fatty acids were detected in both isolates.

$\mathbf{G}+\mathbf{C}$ content. The $\mathrm{G}+\mathrm{C}$ content of the DNA of strain SEBR $2840^{\mathrm{T}}$ was $59.5 \mathrm{~mol} \%$.

16S rRNA gene sequence analysis. We sequenced 1,417 bases from positions 52 to $1461,1,543$ bases from positions 8 to 1542, and 1,541 bases from positions 9 to 1542 (Escherichia coli numbering of Winker and Woese [34]) of the 16S rRNA genes of strain SEBR $2840^{\mathrm{T}}$, Desulfohalobium retbaense, and Desulfovibrio halophilus, respectively. The results of our $16 \mathrm{~S}$ rRNA gene sequence analysis indicated that strain SEBR $2840^{\mathrm{T}}$ clustered with members of the genus Desulfovibrio (average level of similarity, $89 \%$ ) and that its closest relative was Desulfovibrio gigas (level of similarity, 91\%) (Table 3 and Fig. 3). Further analysis revealed that strain SEBR $2840^{\mathrm{T}}$ was distantly related to the halophilic sulfate-reducing bacteria Desulfovibrio halophilus (level of similarity, 88.7\%), Desulfohalobium retbaense (level of similarity, $87 \%$ ), and Desulfovibrio salexigens (level of similarity, $90 \%$ ).

\section{DISCUSSION}

Strains SEBR $2840^{\mathrm{T}}$ and SEBR 3640 , which were isolated from the production water of an oil field, are strictly anaerobic, slightly curved, rod-shaped organisms that use sulfate as an electron acceptor. The presence of desulfoviridin and the ability of these strains to use lactate and alcohols strongly suggest that they are affiliated with the genus Desulfovibrio in the

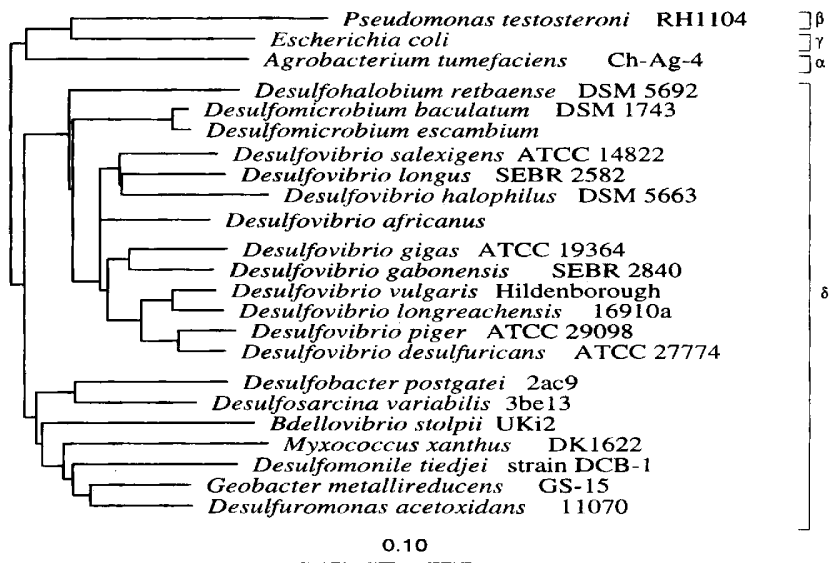

FIG. 3. Phylogenetic tree based on a comparison of the $16 \mathrm{~S}$ ribosomal DNA sequences of Desulfovibrio gabonensis SEBR $2840^{\mathrm{T}}$ and selected bacteria. $\alpha, \beta, \gamma$, and $\delta$ are subdivisions of the Proteobacteria. 
ecophysiological group containing the SRB (24). Because the two strains have very similar physiological and metabolic characteristics, they were considered members of the same species, and strain SEBR 2840 was chosen as the type strain. Both strains require $\mathrm{NaCl}$ for growth, like the four halophilic $D e$ sulfovibrio species described previously, Desulfovibrio desulfuricans subsp. aestuarii $(25,31)$, Desulfovibrio giganteus (13), Desulfovibrio salexigens $(25,31)$, and Desulfovibrio halophilus (9). Strains SEBR $2840^{\mathrm{T}}$ and SEBR 3640 can easily be distinguished from the first three of these species by their $\mathrm{NaCl}$ tolerance. Desulfovibrio desulfuricans subsp. aestuarii, Desulfovibrio giganteus, and Desulfovibrio salexigens are slightly halophilic sulfate reducers (optimal growth occurs at salinities ranging from 1 to $4 \%$ ); in contrast, both strain SEBR $2840^{\top}$ and strain SEBR 3640 are moderately halophilic SRB that grow optimally in the presence of 5 to $8 \% \mathrm{NaCl}$ and are able to grow in the presence of up to $17 \% \mathrm{NaCl}$. The ability to grow in the presence of such high $\mathrm{NaCl}$ concentrations has been observed previously with only two SRB, Desulfovibrio halophilus (9) and Desulfohalobium retbaense (21). Desulfohalobium retbaense is a motile, straight, rod-shaped organism that grows optimally in the presence of $10 \% \mathrm{NaCl}$, incompletely oxidizes lactate, ethanol, and pyruvate, and contains desulforubidin as a bisulfite reductase. Thus, morphologically and physiologically, Desulfohalobium retbaense is different from Desulfovibrio $\mathrm{sp}$. strains SEBR $2840^{\mathrm{T}}$ and SEBR 3640 . Both strain SEBR $2840^{\mathrm{T}}$ and strain SEBR 3640 are more closely related to Desulfovibrio halophilus than to other halophilic SRB. However, they differ from Desulfovibrio halophilus by their ability to oxidize fumarate, succinate, and malate; fermentative growth with malate, fumarate, and pyruvate has not been observed in Desulfovibrio halophilus (Table 4).

Moreover, the phylogenetic data showed that the three halophilic SRB that have been isolated so far are not closely related. Desulfovibrio halophilus and strain SEBR $2840^{\mathrm{T}}$ are affiliated with the Desulfovibrionaceae (11) but are members of two different lines. Strain SEBR $2840^{\mathrm{T}}$ is closely related to Desulfovibrio gigas, whereas Desulfovibrio halophilus belongs to a cluster that includes Desulfovibrio longus and Desulfovibrio salexigens.

The fatty acid profiles of isolates SEBR $2840^{\mathrm{T}}$ and SEBR 3640 are similar in that branched-chain saturated fatty acids predominate and anteiso $C_{15: 0}$ is a major fatty acid. iso $C_{15: 0}$, anteiso $\mathrm{C}_{15: 0}$, and $\mathrm{C}_{17: 0}$ are found in many bacteria, including some aerobic and anaerobic bacteria, like the sulfate reducers $(7,12)$. iso $C_{15: 0}$ is the dominant fatty acid in most Desulfovibrio species and in the genera Desulfomicrobium and Desulfomonas. The percentage of this fatty acid is significantly lower in some other SRB (Desulfovibrio gigas, Desulfovibrio giganteus, and Desulfovibrio sulfodismutans), which have anteiso $\mathrm{C}_{15: 0}$ as their major fatty acid. iso $C_{17: 1 \omega 7}$, which is not present in isolates SEBR $2840^{\mathrm{T}}$ and SEBR 3640 , is usually recognized as a biomarker for the genus Desulfovibrio, although Desulfovibrio gigas DSM 1382 does not contain this monounsaturated acid (27).

The metabolic and physiological characteristics of Desulfovibrio sp. strains SEBR $2840^{\mathrm{T}}$ and SEBR 3640 are different enough from the characteristics of all previously described Desulfovibrio species that these two strains could be considered members of a new species.

This possibility is supported by the $16 \mathrm{~S}$ rRNA gene sequence data, which clearly showed that strain SEBR $2840^{\mathrm{T}}$ belongs to a cluster composed of all of the Desulfovibrio species examined so far. The evolutionary distances between strain SEBR $2840^{\mathrm{T}}$ and other members of the genus Desulfovibrio are large enough to consider strain SEBR $2840^{\mathrm{T}}$ a member of a new species of
TABLE 4. Major characteristics of moderately halophilic Desulfovibrio species

\begin{tabular}{|c|c|c|}
\hline Characteristic & $\begin{array}{l}\text { Desulfovibrio } \\
\text { gabonensis } \\
\text { SEBR } 2840^{\mathrm{T}}\end{array}$ & $\begin{array}{l}\text { Desulfovibrio } \\
\text { halophilus } \\
\text { SL } 8903^{a}\end{array}$ \\
\hline Cell size $(\mu \mathrm{m})$ & $0.4 \times 2-4$ & $0.6 \times 2.5-5$ \\
\hline Salinity range $(\%)$ & $1-17$ & $3-18$ \\
\hline Optimum salinity (\%) & $5-6$ & $6-7$ \\
\hline Desulfoviridin & + & + \\
\hline $\mathrm{G}+\mathrm{C}$ content $(\mathrm{mol} \%)$ & 59.5 & 60.7 \\
\hline Vitamins required & + & - \\
\hline Optimum temp $\left({ }^{\circ} \mathrm{C}\right)$ & 30 & 35 \\
\hline \multicolumn{3}{|c|}{$\begin{array}{l}\text { Utilization of electron donors in } \\
\text { the presence of sulfate }\end{array}$} \\
\hline $\mathrm{H}_{2}+\mathrm{CO}_{2}$ & $--^{b}$ & - \\
\hline $\mathrm{H}_{2}+$ acetate & + & + \\
\hline Lactate & + & + \\
\hline Pyruvate & + & + \\
\hline Malate & + & - \\
\hline Fumarate & + & - \\
\hline Succinate & + & - \\
\hline Formate + acetate & + & + \\
\hline Acetate & - & - \\
\hline Ethanol & + & + \\
\hline Isopropanol & - & - \\
\hline Butanol & $(+)$ & - \\
\hline \multicolumn{3}{|c|}{$\begin{array}{l}\text { Fermentation in the absence of } \\
\text { sulfate }\end{array}$} \\
\hline Pyruvate & + & - \\
\hline Malate & + & - \\
\hline Fumarate & + & - \\
\hline \multicolumn{3}{|c|}{$\begin{array}{l}\text { Utilization of electron acceptors } \\
\text { with lactate as an energy and } \\
\text { carbon source }\end{array}$} \\
\hline Sulfate & + & + \\
\hline Sulfite & + & + \\
\hline Thiosulfate & + & + \\
\hline Sulfur & + & $(+)$ \\
\hline Nitrate & - & - \\
\hline
\end{tabular}

${ }^{a}$ Data from reference 9.

$b_{-}$, no growth; + , good growth; $(+)$, slight growth.

this genus. Therefore, strains SEBR $2840^{\mathrm{T}}$ and SEBR 3640 are considered representatives of a new species named Desulfovibrio gabonensis.

Description of Desulfovibrio gabonensis sp. nov. Desulfovibrio gabonensis (ga. bo' nen. sis. M. L. adj. gabonensis, pertaining to Gabon, a country in West Africa). Curved rod-shaped cells are $0.4 \mu \mathrm{m}$ wide and 2 to $4 \mu \mathrm{m}$ long. Gram negative. Motile by means of a polar flagellum. The $\mathrm{pH}$ range is 6.4 to 8.2 ; optimum growth occurs at $\mathrm{pH} 6.9$ to 7.3 . The temperature range is 15 to $40^{\circ} \mathrm{C}$; optimum growth occurs at $30^{\circ} \mathrm{C}$. The salinity range is 1 to $17 \%$; optimum growth occurs in the presence of 5 to $6 \%$ $\mathrm{NaCl}$.

Strictly anaerobic. Reduces sulfate, sulfite, thiosulfate, and elemental sulfur with production of sulfide. Nitrate is not used as an electron acceptor. The substrates that are oxidized by anaerobic respiration of sulfur compounds are $\mathrm{H}_{2}$, formate, lactate, pyruvate, malate, fumarate, succinate, and ethanol. $\mathrm{H}_{2}$ and formate are used in the presence of acetate. Slight growth occurs with butanol. Malate, fumarate, and pyruvate are fermented. Vitamins are required as growth factors. Desulfoviridin is present. The $\mathrm{G}+\mathrm{C}$ content of the DNA is $59.5 \mathrm{~mol} \%$. The major lipids are anteiso $\mathrm{C}_{15: 0}$ (40\% of the total fatty acids), $\mathrm{C}_{18: 0}(15 \%), \mathrm{C}_{14: 0}(14 \%)$, and $\mathrm{C}_{16: 0}(8 \%)$. The $16 \mathrm{~S}$ rRNA gene sequence has been deposited in the GenBank and EMBL databases under accession number U31080. 

bon.

Habitat: production fluid from an oil-producing well in Ga-

The type strain is strain SEBR 2840, which has been deposited in the Deutsche Sammlung von Mikroorganismen und Zellkulturen as strain DSM 10636.

\section{ACKNOWLEDGMENTS}

We are grateful to S. Jagoueix and P. Jara for helpful discussions about PCR. We thank B. Delpech, O. Bonin, and X. Dumont for helpful technical assistance during ribosomal DNA sequencing.

This research was supported by a grant from Elf Aquitaine (to C.T.-J.) and in part by a grant from the Australian Research Council (to B.K.C.P.).

\section{REFERENCES}

1. Adkins, J. P., L. A. Cornell, and R. S. Tanner. 1992. Microbial composition of carbonate petroleum reservoir fluids. Geomicrobiol. J. 10:87-97.

2. Altshul, S. F., W. Gish, W. Miller, E. W. Myers, and D. J. Lipman. 1990. Basic local alignment search tool. J. Mol. Biol. 215:403-410.

3. Bastin, E., B. Anderson, F. E. Greer, C. A. Merritt, and G. Moulton. 1926 The problem of the natural reduction of sulphates. Bull. Am. Assoc. Petrol. Geol. 10:1270-1299.

4. Bernard, F. P., J. Connan, and M. Magot. 1992. Indigenous microorganisms in connate water of many oil fields: a new tool in exploration and production techniques, paper SPE 24811, p. 467-476. In Proceedings of the 67th Annual Technical Conference and Exhibition of the Society of Petroleum Engineers, Inc. Society of Petroleum Engineers, Inc., Richardson, Tex.

5. Bhupathiraju, V. K., M. J. McInerney, and R. M. Knapp. 1993. Pretest studies for a microbially enhanced oil recovery field pilot in a hypersaline oil reservoir. Geomicrobiol. J. 11:19-34.

6. Bligh, E. G., and W. J. Dyer. 1959. A rapid method of total lipid extraction and purification. Can J. Biochem. Physiol. 37:911-917.

7. Boon, J. J., J. W. De Leeuw, G. J. Van Der Hoek, and J. H. Vosjan. 1977. Significance and taxonomic value of iso and anteiso monoenoic fatty acids and branched $\beta$ hydroxy fatty acids in Desulfovibrio desulfuricans. J. Bacteriol. 129:1183-1191.

8. Brefort, G., M. Magot, H. Ionesco, and M. Sebald. 1977. Characterization and transferability of Clostridium perfringens plasmids. Plasmid 1:52-66.

9. Caumette, P., Y. Cohen, and R. Matheron. 1991. Isolation and characterization of Desulfovibrio halophilus sp. nov., a halophilic sulfate-reducing bacterium isolated from Solar Lake (Sinai). Syst. Appl. Microbiol. 14:33-38.

10. Combet-Blanc, Y., B. Ollivier, C. Streicher, B. K. C. Patel, P. P. Dwivedi, B. Pot, G. Prensier, and J. L. Garcia. 1995. Bacillus thermoamylovorans $\mathrm{sp}$. nov., a moderately thermophilic and amylolytic bacterium. Int. J. Syst. Bacteriol. 45:9-16

11. Devereux, R., S. H. He, C. L. Doyle, S. Orkland, D. A. Stahl, J. LeGall, and W. B. Whitman. 1990. Diversity and origin of Desulfovibrio species: phylogenetic definition of a family. J. Bacteriol. 172:3609-3619.

12. Edlund, A., P. D. Nichols, R. Roffey, and D. C. White. 1985. Extractable and lipopolysaccharide fatty acid and hydroxy acid profiles from Desulfovibrio species. J. Lipid Res. 26:982-988.

13. Esnault, G., P. Caumette, and J. L. Garcia. 1988. Characterization of $D e$ sulfovibrio giganteus $\mathrm{sp}$. nov., a sulfate-reducing bacterium isolated from a brackish coastal lagoon. Syst. Appl. Microbiol. 10:147-151.

14. Felsenstein, J. 1989. PHYLIP - phylogeny inference package (version 3.2). Cladistics 5:164-166.

15. Guezennec, J. G. 1991. Influence of cathodic protection of mild steel on the growth of sulphate-reducing bacteria at $35^{\circ} \mathrm{C}$ in marine sediments. Biofouling 3:339-348.
16. Jukes, T. H., and C. R. Cantor. 1969. Evolution of protein molecules, p. 21-132. In H. N. Munro (ed.), Mammalian protein metabolism. Academic Press, Inc., New York.

17. Love, C. A., B. K. C. Patel, P. D. Nichols, and E. Stackebrandt. 1993. Desulfotomaculum australicum, sp. nov., a thermophilic sulfate-reducing bacterium isolated from the Great Artesian Basin of Australia. Syst. Appl. Microbiol. 16:244-251.

18. Magot, M., P. Caumette, J. M. Desperrier, R. Matheron, C. Dauga, F. Grimont, and L. Carreau. 1992. Desulfovibrio longus sp. nov., a sulfatereducing bacterium isolated from an oil-producing well. Int. J. Syst. Bacteriol. 42:398-403.

19. Nazina, T. N., A. E. Ivanova, and A. V. Blagov. 1992. Microbiological characteristics of oil formations of Mangyshlak Peninsula. Microbiology (Engl. Transl. Microbiologiya) 61:216-221.

20. Nichols, P. D., J. B. Guckert, and D. C. White. 1986. Determination of monounsaturated fatty acid double bond position and geometry for microbial monocultures and complex consortia by capillary GC-MS of their dimethyldisulfur adducts. J. Microbiol. Methods 5:49-55.

21. Ollivier, B. C. E. Hatchikian, G. Prensier, J. Guezennec, and J. L Garcia. 1991. Desulfohalobium retbaense gen. nov., sp. nov., a halophilic sulfatereducing bacterium from sediments of a hypersaline lake in Senegal. Int. J Syst. Bacteriol. 41:74-81.

22. Olsen, G. J., R. Overbeek, N. Larsen, T. H. Marsh, M. J. McCaughey, M. A Maciukenas, W. M. Kuan, T. J. Macke, and C. R. Woese. 1992. The Ribosomal Database Project. Nucleic Acids Res. 20(Suppl.):2199-2200.

23. Pfennig, N., and S. Wagener. 1986. An improved method of preparing wet mounts for photomicrographs of microorganisms. J. Microbiol. Methods 4:303-306.

24. Pfennig, N., F. Widdel, and H. G. Trüper. 1981. The dissimilatory sulfatereducing bacteria, p. 926-940. In M. P. Starr, H. Stolp, H. G. Trüper, A Balows, and H. G. Schlegel (ed.), The prokaryotes, vol. 1. Springer Verlag, New York.

25. Postgate, J. R. 1984. Genus Desulfovibrio, p. 666-672. In N. R. Krieg and J. G. Holt (ed.), Bergey's manual of systematic bacteriology, vol. 1. The Williams \& Wilkins Co., Baltimore.

26. Redburn, A. C., and B. K. C. Patel. 1994. Desulfovibrio longreachii sp. nov. a sulfate-reducing bacterium isolated from the Great Artesian Basin of Australia. FEMS Microbiol. Lett. 115:33-38.

27. Vainshtein, M., H. Hippe, and R. M. Kroppenstedt. 1992. Cellular fatty acid composition of Desulfovibrio species and its use in classification of sulfatereducing bacteria. Syst. Appl. Microbiol. 15:554-556.

28. Weisburg, W. G., S. M. Barns, D. A. Pelletier, and D. J. Lane. 1991. 16S ribosomal DNA amplification for phylogenetic study. J. Bacteriol. 173:697-703.

29. White, D. C., R. J. Bobbie, J. S. Herron, J. D. King, and S. J. Morrison. 1979 Biochemical measurements of microbial mass and activity from environmental samples, p. 69-81. In Native aquatic bacteria: enumeration, activity and ecology. ASTM STP 695. American Society for Testing and Materials, Philadelphia.

30. White, D. C., W. M. Davis, J. S. Nickels, J. D. King, and R. J. Bobbie. 1979 Determination of the sedimentary microbial biomass by extractable lipid phosphate. Oecologia (Berlin) 40:51-62.

31. Widdel, F. 1988. Microbiology and ecology of sulfate- and sulfur-reducing bacteria, p. 469-585. In A. J. B. Zehnder (ed.), Biology of anaerobic microorganisms. John Wiley \& Sons, Inc., New York.

32. Widdel, F., and N. Pfennig. 1981. Studies on dissimilatory sulfate-reducing bacteria that decompose fatty acids. I. Isolation of new sulfate-reducing bacteria enriched with acetate from saline environments. Description of Desulfobacter postgatei gen. nov., sp. nov. Arch. Microbiol. 129:395-400.

33. Wilbur, W. J., and D. J. Lipman. 1983. Rapid similarity searches of nucleic acid and protein data banks. Proc. Natl. Acad. Sci. USA 80:726-730.

34. Winker, S., and C. R. Woese. 1991. A definition of the domains Archaea, Bacteria and Eucarya in terms of small subunit ribosomal RNA characteristics. Syst. Appl. Microbiol. 14:305-310. 